\title{
AL-IQTISHADIYAH
}

Jurnal Ekonomi Syariah dan Hukum Ekonomi Syariah

E-ISSN: 2621-0274; P-ISSN: 2442-2282

Volume 7, Nomor 1, Juni 2021

\section{Analisis Kontribusi Subsektor Industri Kreatif Terhadap Produk Domestik Bruto (PDB) di Tulungagung}

\section{Yourdan Feby Hendrawan ${ }^{1} \&$ Dedi Suselo ${ }^{2}$}

1 Institut Agama Islam Negeri Tulungagung, Indonesia. E-mail: yourdanfebyh@gmail.com

2 Institut Agama Islam Negeri Tulungagung, Indonesia. E-mail: dedisuselo@iain-tulungagung.ac.id

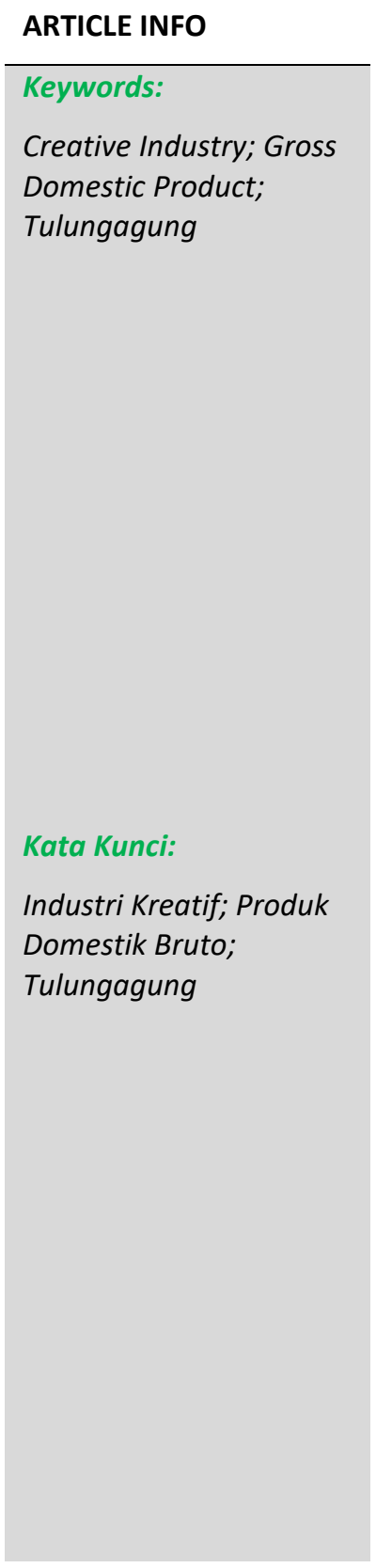

\section{ABSTRACT}

This study aims to analyze the contribution of the creative industry / creative economy to gross domestic product (GDP) in Tulungagung. The method used in this study is a literature review. The data obtained in the study were analyzed qualitatively and descriptively. Descriptive method is used to explain the condition and contribution of 14 creative industry sub-sectors to the economy of Tulungagung Regency. In 2019, the creative industry's contribution to GDP in Tulungagung was IDR 39.22 trillion. The research results obtained 4 leading sectors of the creative industry, namely culinary at 51.69\%, fashion by $41.05 \%$, handicrafts at $38.15 \%$, and performing arts at $37.70 \%$. The contribution of the creative economy to GDP in Tulungagung Regency has entered the medium category. The local government uses a strategy to develop the people's economy, namely by providing training, access to capital, granting official permits, marketing assistance and various socializations. Meanwhile, to maintain the creative economy, namely by maintaining product quality and making innovations according to market developments and current trends.

\section{ABSTRAK}

Penelitian ini bertujuan untuk menganalisis kontribusi industri kreatif/ekonomi kreatif terhadap PDB di Kabupaten Tulungagung. Metode yang digunakan dalam penelitian ini adalah literature review. Data yang diperoleh dalam penelitian dianalisis secara kualitatif dan deskriptif. Metode deskriptif digunakan untuk menjelaskan kondisi dan kontribusi 14 subsektor industri kreatif terhadap perekonomian Kabupaten Tulungagung. Pada tahun 2019, kontribusi industri kreatif terhadap PDB di Tulungagung sebanyak 39.22 triliun rupiah. Hasil penelitian diperoleh 4 sektor unggulan industri kreatif yaitu kuliner sebesar 51,69\%, fashion sebesar $41,05 \%$, kerajinan sebesar 38,15\%, dan seni pertunjukan sebesar $37,70 \%$. Kontribusi ekonomi kreatif terhadap PDB di Kabupaten Tulungagung sudah masuk ke dalam kategori sedang. Pemerintah daerah menggunakan strategi untuk mengembangkan perekonomian rakyat yaitu dengan memberikan pelatihan, akses permodalan, pemberian izin resmi, pendampingan pemasaran dan berbagai sosialisasi. Sedangkan untuk mempertahankan ekonomi kreatif yaitu dengan cara menjaga kualitas produk, serta berinovasi sesuai perkembangan pasar dan trend terkini. 
Jurnal Ekonomi Syariah dan Hukum Ekonomi Syariah

\section{Pendahuluan}

Globalisasi pada zaman sekarang menjadi faktor utama untuk mengurangi berbagai hambatan pada perdagangan maupun ekonomi, pembangunan yang lebih mengedepankan skill, bakat, dan daya kreativitas sangatlah dibutuhkan karena hal tersebut bisa meningkatkan daya saing bangsa dan ditambah lagi dengan adanya persaingan MEA (Masyarakat Ekonomi Asean) yang membuat persaingan antar warga semakin terbuka. Para kreator dan pencetus ide juga terlibat dalam industri kreatif. ${ }^{1}$ Sebagai manusia seharusnya dapat mewujudkan ide atau kreativitas yang telah diciptakan. Adanya fenomena yang berhubungan dengan bidang ekonomi, maka terbentuk ekonomi kreatif sebagai alat untuk meningkatkan pembangunan dan kesejahteraan bagi masyarakat. Ekonomi Kreatif merupakan ekonomi pada periode baru yang difokuskan pada infromasi dan kreativitas. Pada ekonomi kreatif dibutuhkan pengetahuan yang luas serta ide oleh manusia. ${ }^{2}$

Industri kreatif adalah bagian dari ekonomi kreatif. Industri kreatif ikut andil dalam berbagai aspek kehidupan baik secara ekonomi atau tidak, sehingga berperan penting terhadap perekonomian nasional dan global. ${ }^{3}$ Adanya industri Kreatif dapat digunakan dalam menghadapi persaingan perekonomian dunia. Oleh karena itu peran pemerintah pusat dan pemerintah daerah sangat penting untuk mendukung kreativitas dan pengembangan ekonomi supaya dapat bersaing dengan negara lain. Pengembangan industri krearif supaya tidak kalah saing dengan daerah lain memerlukan strategi, salah satunya adalah peran tiga aktor untuk berkontribusi dan berkolaborasi mewujudkan industri kreatif. $^{4}$ Ketiga aktor tersebut adalah cendekiawan, pembisnis, dan pemerintah. ${ }^{5}$ Apabila ketiga aktor tersebut tidak ada, maka pengembangan industri tidak akan berjalan lancar dan akan tumpang tinding karena tidak sesuai dengan rencana yang telah disiapkan. ${ }^{6}$

Ekonomi kreatif nasional terus berkembang, terbukti dari sumbangan PDB yang

\footnotetext{
${ }^{1}$ Amir, M. Kebijakan Ekonomi Kreatif Berbasis Industri Kerajinan Unggulan dalam Upaya Mengangkat Kearifan Lokal Kabupaten Tuban, Jurnal Cakrawala, Vol.11 No.2 Desember 2017. hal.158.

2 Polnaya, G. A, dan Darwanto. Pengembangan Ekonomi Lokal Untuk Meningkatkan Daya Saing Pada UKM Ekonomi Kreatif Batik Bakaran di Pati, Jawa Tengah. Jurnal Bisnis dan Ekonomi (JBE),Vol. 22 No.1 Maret. 2015.hal.4.

${ }^{3}$ Suryana. Ekonomi Kreatif, Ekonomi Baru: Mengubah Ide dan Menciptakan Peluang. Jakarta Selatan. 2013

${ }^{4}$ Andry, M. S. N. Pendekatan Desain bagi Industri Kerajinan Kreatif: Sebuah Usulan bagi Program Implementasi Ekonomi Kreatif di Sektor Industri Kerajinan Indonesia. Disampaikan pada Seminar Nasional "Strategi UMKM dan IKM Menghadapi Asean China Free Trade Area (ACFTA) dan Implementasinya dalam Upaya Memperkuat dan Mengembangkan Kemampuan Diri". 2010

${ }^{5}$ Yasniasari, A., I. Noor., dan W. Y. Prasetyo. Strategi Dinas Perindustrian Dan Perdagangan Dalam Mengembangkan Industri Kreatif Sektor Kerajinan Batu Marmer Untuk Meningkatkan Daya Saing Daerah (Studi Di Dinas Perindustrian Dan Perdagangan Kabupaten Tulungagung). Jurnal Administrasi Publik (JAP), Vol. 3, No. 5, Hal. 775-781.

${ }^{6}$ Pangestu, M. I. Pengembangan Ekonomi Kreatif Indonesia 2025. Rencana Pengembangan Ekonomi Kreatif Indonesia 2009-2015. Departemen Perdagangan Republik Indonesia.2008.
} 
mengalami kenaikan pada tiga tahun terakhir. Kamar Dagang dan Industri (Kadin) memprediksi jika ekonomi kreatif akan berkontribusi terhadap PDB sebesar Rp 1.211 triliun pada tahun 2019, naik dari 2018 sebesar Rp 1.105 triliun, sedangkan pada 2017 sebesar Rp 1.000 triliun. Menurut Triawan pada konferensi pers WWCE (World Conference on Creative Ekonomi) Tahun 2018 sub sektor fashion, kuliner, dan kriya menjadi tiga subsektor tertinggi, sedangkan yang menjadi subsektor prioritas adalah musik, film, pengembangan aplikasi serta permainan. ${ }^{7}$

Manusia akan memanfaatkan potensi yang dimiliki oleh setiap daerahnya untuk melangsungkan hidup. ${ }^{8}$ Peningkatan Ekonomi Kreatif juga dilakukan di Kabupaten Tulungagung. Mengingat Kabupaten Tulungagung merupakan salah satu Kabupaten yang mendapatkan julukan sebagai Kota Marmer. Hal ini dikarenakan Tulungagung memiliki kekayaan alam yang melimpah dan didukung oleh kekayaan seni budaya dan kearifan lokal masyarakatnya membuat Pemerintah Daerah ingin meningkatkan Ekonomi Kreatif di Kabupaten Tulungagung. Dengan adanya potensi yang ada baik potensi industri, potensi ekspor dan potensi unggulan yang dimiliki Tulungagung apabila terus dikembangkan maka akan bisa mewujudkan kesejahteraan bagi masyarakat Tulungagung.

Ekonomi Kreatif di Kabupaten Tulungagung ada 12 subsektor, 7 subsektor sudah mendapatkan binaan dari Dinas Kebudayaan dan Pariwisata Tulungagung dan dari ketujuh subsektor tersebut yang memiliki perkembangan yang paling bagus ada 4 subsektor. Subsektor yang dimaksud yang dikembangkan di Tulungagung yaitu kriya, fashion, seni rupa, seni pertunjukan, kuliner, arsitek, televisi, editing video, desain interior, desain produk, fotografi, musik. ${ }^{9}$ Adanya 12 subsektor ini menjadi tugas bagi pemerintah daerah untuk meningkatkan ekonomi kreatif itu sendiri. Pemerintah saat ini sangat mendukung dengan keberadaan ekonomi kreatif, karena memberikan kontribusi penuh terhadap peningkatan lapangan kerja, sumbangan terhadap PBD, menciptakan iklim bisnis, menciptakan inovasi dan kreativitas yang menjadi unggulan bagi daerah serta memberikan dampak positif untuk meningkatkan kualitas hidup.

Sebagaimana penelitian yang dilakukan oleh Akbar Gunawan, Putiri Bhuana Katili, Mukti Lestari (2017), dengan judul "Pemetaan Potensi Industri Kreatif Unggulan Untuk Meningkatkan Pertumbuhan Ekonomi." Tujuan dari penelitian ini adalah mengembangkan perekonomian Kota Cilegon dengan strategi memaksimalkan pemetaan industri kreatif unggulan. Hasil penelitian menunjukan jika Kota Cilegon mengalami pertumbuhan ekonomi lebih cepat dibandingkan Provinsi Banten, dimana nilai Dij/dampak riil pertumbuhan positif. Industri kreatif berkontribusi nyata dan signifikan. Subsektor unggulan Kota Cilegon adalah kerajinan dan fashion yang

\footnotetext{
${ }^{7}$ Badan Ekonomi Kreatif Indonesia 2019. BEKRAF.go.id.

${ }^{8}$ Malihah, N., dan S. Achiria. Peran Ekonomi Kreatif Dalam Pemberdayaan Industry Kerajinan Bambu. Jurnal Kajian Ekonomi Islam Volume 4 Nomor 1 Januari-Juni 2019.

9 Khusna, M. K. Peran Pemerintah Daerah Untuk Meningkatkan Ekonomi Kreatif Di Kabupaten Tulungagung. Skripsi. Jurusan Ekonomi Syariah. Fakultas Ekonomi dan Bisnis Islam IAIN Tulungagung. 2020.
} 
memiliki nilai efisiensi 1 diukur dari tingkat efisiensi. ${ }^{10}$

Penelitian oleh Rachmad Hidayat (2015) berjudul "Pemetaan Potensi Industri Kreatif Unggulan Madura." Penelitian ini bertujuan untuk menentukan industri kreatif unggulan Kabupaten Bangkalan Madura dari 14 subsekor berdasarkan variabel yang digunakan Departemen Perdagangan RI 2007 sesuai KBLI (Klasifikasi Baku Lapangan. Berdasarkan hasil penelitian, ditunjukkan tiga subsektor unggulan antara lain; fashion, video, film dan fotografi yang didapatkan dari pengukuran efisiensi metode DEA. ${ }^{11}$

Penelitian oleh Azka Dwi Asa (2019) berjudul "Analisis produk Domestik Bruto Indonesia Melalui Sektor Ekonomi Kreatif Periode 2010-2016." Tujuan dari penelitian ini adalah untuk mengetahui pengaruh dari ekspor, tenaga kerja, dan rata-rata upah terhadap Produk Domestik Bruto (PDB) Indonesia melaui sektor ekonomi kreatif pada periode 2010 - 2016. Objek yang digunakan adalah tujuh dari enam belas subsektor ekonomi kreatif yaitu kriya, musik, film animasi dan video, kuliner, fesyen, seni rupa, serta penerbitan. Metode yang digunakan adalah data sekunder dan kuantitatif menggunakan uji regresi data panel dan pendekatan Random Effect Model. Hasil penelitian didapatkan bahwa terdapat pengaruh positif antara ekspor, tenaga kerja, dan rata-rata upah terhadap PDB ekonomi kreatif periode 2010-2016. ${ }^{12}$

Berdasarkan pemaparan di atas, penelitian ini bertujuan untuk menganalisis kontibusi subsektor industri kreatif terhadap penerimaan domestik bruto (PDB) di Tulungagung.

\section{Kajian Teori}

\section{Pemberdayaan}

Pemberdayaan didefinisikan sebagai peningkatan bagi masyarakat yang lemah dan kurang beruntung. Rappaport menjelaskan bahwa pemberdayaan berarti strategi pengarahan terhadap rakyat atau suatu kelompok supaya dapat berkuasa atas kehidupan yang dimilikinya. ${ }^{13}$ Menurut Aristianto, bahwa Pemberdayaan adalah langkah untuk mengembangkan kemampuan masyarakat dengan cara memotivasi dan memberikan kesadaran mengenai potensi dalam dirinya supaya terdorong untuk meningkatkan potensi tersebut. ${ }^{14}$

\footnotetext{
${ }^{10}$ Gunawan, Akbar; Katili, Putiri Bhuana; Lestari, Mukti. Pemetaan potensi industri kreatif unggulan untuk meningkatkan pertumbuhan ekonomi. Journal Industrial Servicess, 2017, 3.1b.

11 Hidayat, Rachmad. "Pemetaan Potensi Industri Kreatif Unggulan Madura." Jurnal Sains dan Teknologi Industri 12.2 (2015): 155-165.

${ }^{12}$ Asa, Azka Dwi. Analisisproduk Domestik Bruto Indonesia Melalui Sektor Ekonomi Kreatif Periode 2010-2016. BS thesis. Jakarta: Fakultas Ekonomi Dan Bisnis UIN Syarif Hidayatullah. 2019.
}

13 Adi Fahrudin, Pemberdayaan, Partisipasi dan Penguatan Kapasitas Masyarakat, (Bandung: Humaniora, 2012).

14 Aristianto, Awit. "Pemberdayaan Keluarga Lansia Melalui Usaha Ekonomi Produktif Oleh Bina Keluarga Lansia Ayah Bunda Ceria Kelurahan Tamanan Tulungagung Perspektif Ekonomi Islam." 
Pemberdayaan masyarakat bertujuan meningkatkan skill masyarakat untuk membangun kemajuan dan perubahan yang lebih baik yang berhubungan dengan pertumbuhan ekonomi. ${ }^{15}$

Berdasarkan beberapa pengertian pemberdayaan di atas, dapat disimpulkan bahwa pemberdayaan merupakan langkah yang dilakukan individu ataupun suatu kelompok tertentu untuk memberikan pembelajaran kepada masyarakat melalui media keterampilan, mengembangkan wawawan, dan peningkatan potensi untuk terciptanya kemandirian pada masyarakat pada bidang ekonomi, sosial, budaya, pendidikan. ${ }^{16}$ Adanya pemberdayaan, dapat membuat masyarakat lebih berdaya untuk meningkatkan potensi dengan mengikuti kegiatan swadaya sehingga sumber daya manusia lebih produktif. ${ }^{17}$ Pemberdayaan dibentuk dengan tujuan untuk membangun potensi masayarakat untuk kegiatan positif secara berkelanjutan. Sehingga, adanya pemberdayaan dapat dimanfaatkan oleh masyarakat untuk memilih sesuatu yang bermanfaat bagi dirinya. Oleh karena itu, pemberdayaan akan diarahkan untuk menjadikan masyarakat yang lebih maju di berbagai aspek salah satunya pemberdayaan ekonomi. ${ }^{18}$

\section{Industri Ekonomi Kreatif}

Ekonomi kreatif diartikan sebagai perpaduan antara informasi dan kreativitas yang bersumber dari gagasan atau pengetahuan manusia sebagai faktor produksi. Pada bidang ekonomi terdapat empat faktor produksi, antara lain modal yang menjadi faktor utama, sumber daya alam (SDA), sumber daya manusia (SDM), dan industri kreatif. ${ }^{19}$ Ekonomi kreatif merupakan perwujudan dari pembangunan berkelanjutan, dimana mampu berdaya saing serta memiliki cadangan sumberdaya yang terbarukan. Ekonomi kreatif dapat dikatakan sebagai manifestasi bagi negara berkembang untuk bertahan hidup. Ekonomi kreatif berperan besar dalam memanfaatkan sumberdaya berupa ide, pengetahuan, potensi, serta kreativitas. ${ }^{20}$

\footnotetext{
(2018).

${ }^{15}$ Noor, M. Pemberdayaan masyarakat. CIVIS, 1(2/Juli). 2011.

16 Hilman, Yusuf Adam, and Elok Putri Nimasari. "Model Program Pemberdayaan Masyarakat Desa Berbasis Komunitas." ARISTO 6.1 (2018): 45-67.

17 Pusut, Risky, Marthen Kimbal, and Michael Mamentu. "Pembangunan Berbasis Pemberdayaan Masyarakat Di Desa Pasir Putih Kecamatan Pamona Selatan Kabupaten Poso." Jurnal Eksekutif 2.2 (2017).

${ }^{18}$ Isyanto, Prio Tri. Pemberdayaan Masyarakat Melalui Pengembangan Badan Usaha Milik Desa (Bum Desa) Di Desa Gogik Kecamatan Ungaran Barat Kabupaten Semarang. Diss. Universitas Negeri Semarang, 2017.

${ }^{19}$ Arjana, I Gusti Bagus. Geografi Pariwisata dan Ekonomi Kreatif, Edisi 1, Cetakan 2, Rajawali Pers, Jakarta. 2016.

${ }^{20}$ Ali, Nasrudin. Peran Ekonomi Kreatif Dalam Pemberdayaan Ekonomi Masyarakat Di Desa Tulung Agung Kecamatan Gading Rejo Kabupaten Pringsewu (Pengrajin Anyaman Bambu). Diss. UIN Raden
} 
Industri Kreatif menjadi bagian dari ekonomi kreatif yang memiliki tujuan masing-masing setiap industri didalamnya. ${ }^{21}$ Kegiatan kreatif dapat digunakan untuk memenuhi kebutuhan pasar melalui inovasi mengenai ilmu pengetahuan dan teknologi, produk baru, alat baru, strategi dan metode baru. Visi pemerintah menjelaskan definisi industri kreatif sebagai industri yang dipengaruhi kreativitas individu, potensi serta keterampilan yang dimiliki oleh sumber daya manusia guna untuk menciptakan tenaga kerja dan dapat digunakan untuk memenuhi kebutuhan hidup..22 Menurut Departemen Perdagangan pada studi pemetaan industri kreatif tahun 2007 dalam buku Pengembangan Ekonomi Kreatif Indonesia $2025^{23}$ menjelaskan bahwa industri merupakan pemanfaatan segala bentuk bakat, keterampilan, dan kreativitas individu yang bertujuan untuk mengembangkan kesejahteraan sdan menciptakan lapangan dengan mengembangkan kreasi dan kreativitas yang telah diciptakan.

Menurut Departemen Perdagangan RI pada buku Pengembangan Industri Kreatif Menuju Visi Ekonomi Kreatif 2025, industri kreatif terbagi menjadi 14 subsektor, antara lain :

a. Periklanan (advertising)

Industri kreatif subsektor periklanan meliputi kegiatan mengkreasikan, memproduksi dan mendistribusikan suatu iklan, misalnya: merencanakan komunikasi iklan luar ruang, memproduksi bahan pembuatan iklan, melakukan promosi, kampanye, menampilkan iklan pada media eletronik atau cetak, pemasangan berbagai poster dan gambar, dan sebagainya. Industri periklanan bergerak dalam bidang jasa pembuatan iklan melalui komunikasi satu arah.

\section{b. Arsitektur}

Industri Arsitektur meliputi kegiatan desain bangunan, perencanaan suatu kota, pengawasan kontruksi, dan sebagainya. Kegiatan ini terbagi dari level makro seperti urban design, landscape architecture, town planning, dan level makro seperti detail kontruksi.

\section{c. Pasar Barang Seni}

Industri kreatif ini berkaitan dengan penjualan barang-barang asli, langka, dan unik yang memiliki nilai keindahan seni yang tinggi. Pengadaan pasar seni dapat dilakukan secara lelang. Tempata atau lokasi bisa dilakukan di toko,

\footnotetext{
Intan Lampung, 2019.

${ }^{21}$ Puspa, D., dan Czafrani, S. (2010). Pengembangan Ekonomi Kreatif Berbasis Kearifan Lokal Oleh Pemuda Dalam Rangka Menjawab Tantangan Ekonomi Global. Jurnal UI Untuk Bangsa Seri Sosial Humaniora, 1.

22 Putra, Dzikri Prakasa, M. Ridha Alhamdani, and Ivan Gunawan. Pusat Industri Kreatif di Kota Pontianak. Diss. Tanjungpura University, 2013.

${ }^{23}$ Pangestu, M. I. Pengembangan Ekonomi Kreatif Indonesia 2025. Rencana Pengembangan Ekonomi Kreatif Indonesia 2009-2015. Departemen Perdagangan Republik Indonesia.2008.
} 
galeri, swalayan, ataupun internet. Produk yang dipasarkan dapat berupa kerajinan, musik, film, percetakan. Adanya pasar seni dapat mengembangkan perkonomian masayarakat.

d. Kerajinan

Industri kreatif kerajinan berhubungan dengan proses produksi, berkreasi, dan distribusi suatu produk oleh seorang pengrajin. Kerajinan dibuat dari proses penentuan desain awal hingga penyelesaian produk. Produk kerajinan dapat dibuat dari bahan alami atau buatan. Kerajinan yang dibaut antara lain berasal dari bahan kayu, kulit, rotan, besi, tanah liat, kaca, marmer, kapur, dan sebagainya

e. Desain

Desain merupakan kegiatan untuk tujuan mengkreasikan sesuatu seperti mendesain produk, interior, desain grafis, industri, serta desain untuk melakukan promosi terhadap barang atau jasa suatu perusahaan.

f. Fesyen (fashion)

Industri fashion berkaitan dengan kegiatan mendesain pakaian, alas kaki, aksesoris, dan fesyen lainnya. Industri kreatif fesyen menjadi salah satu pendorong tertinggi perekonomian Indonesia. Saat ini, banyak sekali industri dibidang fashion muslim dan bermunculan nama designer baru yang berbakat.

g. Video, Film dan Fotografi

Subsektor ini berkaitan dengan pembautan atau memproduksi video, film, rekaman, foto, termasuk membuat tulisan skrip, sinematografi, dubbing, dan sinetron.

h. Permainan Interaktif (game)

Industri Kreatif permainan interaktif disebut sebagai kegiatan yang mengandung unsur kreativitas berkaitan dengan proses produksi, kreasi, dan distribusi permainan komputer, didalamya berisi video yang bertujuan untuk menghibur, atau mengedukasi.

i. Musik

Industri Kreatif ini berkaitan dengan pertunjukan musik, reproduksi, komposisi, serta mendistribusikan rekaman suara.

j. Seni Pertunjukan (showbiz)

Subsektor ini berkaitan dengan kegiatan pertunjukan ataupun pembuatan konten. Seni pertunjukan antara lain; tari tradisional dan kontemporer, balet, teater, drama, musik teater, etnik, dan tradisional, opera, pertunjukan busana, dan sebagainya. 


\section{k. Penerbitan dan Percetakan}

Industri subsektor penerbitan dan percetakan berkaitan dengan pembuatan konten tulisan serta penerbitan buku, majalah, koran, jurnal, tabloid, artikel, dan lain-lain. Subsektor ini juga melakukan penerbitan uang kertas, materai, giro, cek, perangko, surat andil, passport, tiket pesawat, obligasi surat saham, dan terbitan khusus lainnya.

I. Layanan Komputer dan Piranti Lunak (software)

Sub sektor layanan komputer dan piranti lunak berkaitan dengan pengembangan teknologi informasi seperti jasa layanan pada komputer, pengembangan perangkat lunak, analisis dan integrasi sistem, desain, perangkat lunak dan keras, dan desain portal.

\section{m. Televisi \& Radio (broadcasting)}

Televisi dan radio adalah media yang dapat dimanfaatkan un tuk kegiatan usaha kreasi, produksi dan penampilan berbagai acara khususnya di televisi seperti kuis, game ataupermainan, infotainment, dan lain sebagaianya. Televisi dan radio juga digunakan untuk kegiatan penyiaran dan transmisi konten acara.

\section{n. Riset dan Pengembangan (R\&D)}

Industri Kreatif ini meliputi kegiatan kreatif yang berkaitan dengan inovatif. RnD dimanfaatkan untuk proses penemuan IPTEK dan diterapkan dalam perbaikan atau pemberbaharuan suatu produk, proses, alat, bahan dan teknologi. Selain itu, berhubungan juga dengan humaniora seperti pengembangan riset serta bahasa, seni dan sastra, dan bisnis atau manajemen. Munculnya penemuan baru dapat digunakan untuk memenuhi kebutuhan pasar. ${ }^{24}$

\section{Optimalisasi Industri Kreatif terhadap Produk Domestik Bruto}

Produk Domestik Bruto (PDB) digunakan sebagai indikator ekonomi untuk mengasumsikan bagaimana keadaan perekonomian di Indonesia. Produk Domestik Bruto ialah penilaian pasar yang dilakukan oleh faktor produksi terhadap seluruh barang atau jasa yang didapatkan diakhir waktu periode tertentu pada suatu lokasi. ${ }^{25}$ Produk Domestik Bruto juga diartikan sebagai penilaian pada barang atau jasa akhir yang telah diproduksi. Perlu dilakukan penekanan pada jasa dan barang terakhir untuk menghindari penghitungan ganda. Mengindari perhitungan ganda dilakukan dengan nilai tambah yang dihitung sebagai bagian PDB.

\footnotetext{
${ }^{24}$ Pangestu, M. I. Pengembangan Ekonomi Kreatif Indonesia 2025. Rencana Pengembangan Ekonomi Kreatif Indonesia 2009-2015. Departemen Perdagangan Republik Indonesia.2008.

${ }^{25}$ Arif, Dodi. "Pengaruh produk domestik bruto, jumlah uang beredar, inflasi dan BI rate terhadap indeks harga saham gabungan di Indonesia periode 2007-2013." Jurnal Ilmiah Ekonomi Bisnis 19.3 (2014).
} 
Sejak tahun 2014-2016, PDB Ekonomi Kreatif Indonesia mengalami peningkatan. Tahun 2014, PDB yang dihasilkan oleh ekonomi kreatif memiliki sebesar 784,87 triliun rupiah, yang menunjukkan adanya peningkatan 17,55\% pada tahun 2016 sehingga menjadi 922,59 triliun rupiah. PDB ekonomi kreatif mengalami ratarata pertumbuhan setiap tahun pada periode tersebut sebesar 9,22\%. Sedangkan, pertumbuhan rata-rata PDB non Ekonomi Kreatif setiap tahun pada periode tersebut sebesar 9,13\%. Adapun pertumbuhan ekonomi merupakan kenaikan PDB baik dalam kenaikan lebih kecil atau lebih besar yang selanjutnya bandingkan dengan tingkat pertumbuhan masyarakat. Keadaan dimana suatu perekonomian mengalami peningkatan dalam masa waktu yang lama dapat diketahui dari pendapatan per kapita menunjukkan bahwa terjadi perkembangan sektor ekonomi.

PDB ekonomi kreatif berkontribusi cukup besar pada perekonomian Indonesia, akan tetapi tidap semua subsektor ekonomi kreatif dapat ekspor. Sebagai contoh kontribusi ekonomi kreatif terhadap PDB Indonesia yaitu kontribusi fesyen pada tahun 2016 yang mampu memberikan hingga 170 trilyun Rupiah. Perkembangan sektor fesyen baik skala kecil, menengah, atau besar sangat memberikan dampak positif pada perekonomian di Indonesia terbukti dengan kegiatan ekspor, upah, dan tenaga kerja yang meningkat. Kontribusi pada PDB kedua adalah industri kriya tahun 2016 yang memberikan 145 Trilyun Rupiah, dan meningkat setiap tahun. Meningkatnya industri kiriya tentunya juga mempengaruhi pertumbuhan ekonomi di Indonesia yang juga semakin pesat. Kontribusi industri kuliner merupakan kontribusi terbaik pada PDB Indonesia yaitu sebesar 384 trilyun rupiah. Keberhasilan industri kuliner disebabkan karena beragam warisan budaya dan maraknya promosi seperti food vlogger di media sosial. Industri kuliner telah menyumbang 1,2 milyar US\$ melalui kegiatan ekspor.

Adapun strategi untuk mengembangkan ekonomi kreatif dibutuhkan kolaborasi antara tiga aktor yang terdiri dari pemerintah, cendekiawan, dan pelaku bisnis. Kolaborasi dari ketiga aktor tersebut akan menjadi pondasi pengembangan industri kreatif yang berkelanjutan dan berbasis ilmu pengetahuan. Teori mengenai adanya kolaborasi ketiga aktor ini disebut sebagai Triple Helix yang awalnya dipopulerkan oleh Etzkowitz dan Leydersdorff yang digunakan sebagai strategi dalam pembangunan berbasis inovasi. ${ }^{26}$

\section{Metode Penelitian}

Penelitian ini menggunakan pendekatan kualitatif dengan pendekatan deskriptif. Pendekatan kualitatif adalah langkah dalam penelitian yang akan menghasilkan

\footnotetext{
${ }^{26}$ Andry, M. S. N. Pendekatan Desain bagi Industri Kerajinan Kreatif: Sebuah Usulan bagi Program Implementasi Ekonomi Kreatif di Sektor Industri Kerajinan Indonesia. Disampaikan pada Seminar Nasional "Strategi UMKM dan IKM Menghadapi Asean China Free Trade Area (ACFTA) dan Implementasinya dalam Upaya Memperkuat dan Mengembangkan Kemampuan Diri". 2010.
} 
olahan berupa kata-kata, baik tulis maupun lisan yang didapatkan dari narasumber ataupun peristiwa yang diamati. ${ }^{27}$ Pendekatan kualitatif juga diartikan sebagai langkah dalam memecahkan masalah yang sedang diselidiki dengan cara menggambarkan atau melukiskan keadaan secara fakta yang diamati. Peneliti akan mengembangkan setiap komponen untuk dianalisis yang diperoleh dari data primer. Data kualitatif adalah sumber awal yang dideskripsikan secara luas yang berisi penjelasan bagaimana proses yang telah terjadi pada lingkup sektor atupun lokal. ${ }^{28}$

Data primer yang digunakan dalam penelitian ini adalah 14 sektor industri kreatif di Kabupaten Tulungagung yang kemudian dianalisis sub sektor unggulan pada wilayah tersebut.

Data kemudian dianalisis menggunakan metode scoring/skor. Tahapan yang dilakukan adalah menentukan nilai rata-rata subsektor, kemudian mengklasifikasikannya berdasarkan kategori nilai. Penentuan kategori skor dapat dilihat pada Tabel 1. Berikut ini.

\section{Tabel 1. Penilaian Kategori Subsektor dalam Persentase}

\begin{tabular}{ccc}
\hline No & Tingkat Keunggulan & Skor \\
\hline 1 & Rendah & $40-59$ \\
\hline 2 & Sedang & $60-79$ \\
\hline 3 & Tinggi & $80-99$ \\
\hline
\end{tabular}

Berikutnya untuk mencapai tujuan penelitian ini, analisis yang akan digunakan antara lain:

1. Analisis faktor-faktor yang mempengaruhi ekonomi kreatif.

Tujuan dari analisis ini adalah mendapatkan informasi mengenai faktor apa saja yang dapat memajukan ekonomi kreatif dalam hal memperluas produk unggulan berbasis kearifan lokal. Analisis dilakukan dengan mempersepsikan bahwa produk lokal dapat meningkatkan ekonomi kreatif sesuai kreativitas masingmasing.

2. Analisis dukungan dan hambatan pada ekonomi kreatif pada sektor unggulan dengan tujuan untuk mengangkat kearifan lokal Kabupaten Tulungagung.

\footnotetext{
27 Sidiq, Umar, Moh Miftachul Choiri, and Anwar Mujahidin. "Metode Penelitian Kualitatif di Bidang Pendidikan." Ponorogo, Jawa Timur, Indonesia: Penerbit CV Nata Karya. Wujud secara online pula di: http://repository. iainponorogo. ac. id/484/1/METODE [dilayari di Kuala Lumpur, Malaysia: 10hb Februari 2020] (2019).

${ }^{28}$ Nugrahani, Farida, and M. Hum. "Metode Penelitian Kualitatif." Solo: Cakra Books (2014).

${ }^{29}$ Surur, Fadhil. "Pengembangan Jalur Ekonomi Kreatif di Koridor Jalan Trans Sulawesi Berbasis Sistem Informasi Geografis." (2017): 1-17.
} 


\section{Pembahasan}

\section{Sektor Industri Kreatif di Tulungagung}

Kabupaten mengalami peningkatan jumlah pelaku ekonomi kreatif dari tahun 2016 sampai tahun 2019 mengalami peningkatan dari jumlah 20 orang menjadi 109 orang. Hal tersebut bisa menjadi acuan bahwa ekonomi kreatif di Tulungagung terus mengalami perkembangan dengan munculnya pelaku ekonomi kreatif. Perkembangan tersebut dibuktikan dengan semakin banyaknya masyarakat yang memiliki usaha disektor ekonomi kreatif. Pemerintah melalui Dinas Kebudayaan dan Pariwisata Kabupaten Tulungagung selalu memberikan dukungannya dalam bentuk pelatihan kepada pelaku ekonomi kreatif, sehingga ekonomi kreatif semakin berkembang. ${ }^{30}$ Berikut perkembangan jumlah pelaku usaha di Tulungagung:

\section{Gambar 1. Perkembangan Jumlah Pelaku Ekonomi Kreatif di Tulungagung Tahun 2016-2019}

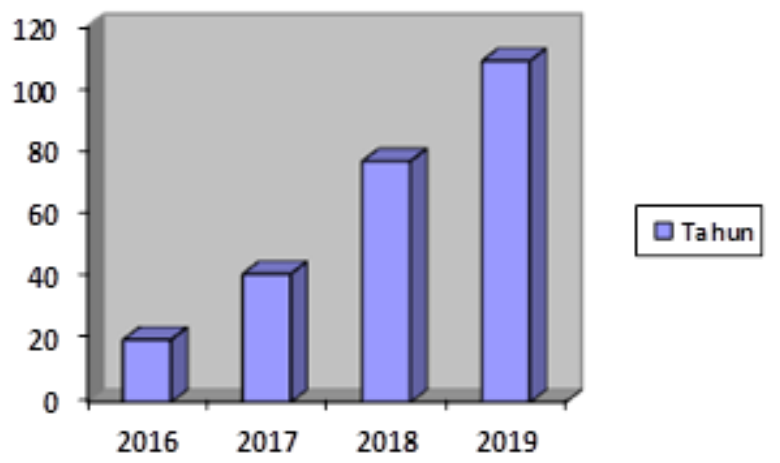

Sumbe: Dinas Kebudayaan dan Pariwisata Tulungagung

Perkembangan ekonomi kreatif di Tulungagung saat ini sudah mulai berkembang pesat. Mulai dari usaha pemanfaatan limbah pantai yang dijadikan hiasan dari daerah besole, juga hiasan dinding yang dibuat dari lempengan bekas kaleng minum yang diukir menjadi suatu gambar. Selain itu ada juga pengrajin kain sibori dengan menggunakan limbah daun untuk pencetakan dikain. Sehingga kain yang mulanya polos menjadi ada gambarnya yang memiliki bentuk dari serat-serat daun. Sehingga dilihat dari perkembangannya lama kelamaan semakin banyak peminatnya. Barang/produk yang dihasilkan memiliki nilai estetika tersendiri. Cara mempertahankan para penikmatnya pelaku usaha harus memiliki inovasi-inovasi baru dan juga selalu mengembangkan kreativitas supaya menjadi barang yang banyak peminatnya. ${ }^{31}$ Harapan selanjutnya di Kabupaten Tulungagung makin banyak para pelaku usaha industri kreatif. Selain

\footnotetext{
30 Khusna, M. K. Peran Pemerintah Daerah Untuk Meningkatkan Ekonomi Kreatif Di Kabupaten Tulungagung. Skripsi. Jurusan Ekonomi Syariah. Fakultas Ekonomi dan Bisnis Islam IAIN Tulungagung. 2020.

31 Juwita, R. Analisis Peran Dinas Kebudayaan Dan Pariwisata Kabupaten Tulungagung Dalam Perkembangan Perekonomian Usaha Ekonomi Kreatif. Laporan Praktik Pengalaman Lapangan Jurusan Ekonomi Syariah. Fakultas Ekonomi dan Bisnis Islam IAIN Tulungagung. 2020.
} 
itu dari subsektor fashion yaitu batik. Kabupaten Tulungagung terletak di bagian selatan Jawa Timur yang dikenal dan memiliki beberapa jenis batik dengan desain yang khas. Batik Tulungagung tidak berbeda jauh dengan batik daerah lainnya, yang membedakan adalah motif dan kekuatan perpaduan warna yang merupakan ciri khas daerah Tulungagung. Salah satu industri batik yang terkenal di Kabupaten Tulungagung adalah Batik Satrio Manah. Batik satrio manah sudah berkembang di Desa Bangoan. ${ }^{32}$

\section{Upaya Pemerintah Daerah Dalam Mendukung Industri Kreatif Di Tulungagung}

Stategi yang dilakukan oleh Pemerintah untuk kelangsungan pertumbuhan ekonomi kreatif antara lain:

1. Jumlah pelaku usaha ekonomi kreatif ditingkatkan.

2. Pengembangan ruang-ruang yang dapat dimanfaatkan untuk mengembangkan, menggali, dan menciptakan kreativitas dengan memanfaatkan ilmu pengetahuan dan teknologi. Pengembangan potensi sumber daya lokal dengan melibatkan pemerintah, akademisi, komunitas, dan bisnis.

3. Apresiasi terhadap kreativitas dan pengetahuan masyarakat.

4. Mendukung pengembangan kreativitas dengan disediakan infrastruktur teknologi yang memadai.

5. Mendukung kreativitas dengan membentuk sebuah kelembagaan terkait.

6. Meningkatkan upaya promosi dan pemasaran hasil karya masyarakat baik dalam negeri ataupun luar negeri.

7. Memberikan pelatihan kepada para pelaku usaha ekonomi kreatif supaya semakin berkembang dan tidak kalah saing dengan daerah lain. (bappeda.tulungagung.go.id).

Dinas Perindag juga melakukan beberapa stategi guna meningkatkan sektor industri kreatif dengan cara: Melandaskan ekonomi kreatif yang tangguh dan unggul, mendukung pengembangan industri kecil atau menengah, melakukan pengelolaan lingkungan, meningkatkan daya saing terhadap daerah lain, menciptakan standarisasi produk, dan menciptakan ekonomi berkelanjutan. ${ }^{33}$

\section{Analisis Kontribusi Industri Kreatif/Ekonomi Kreatif Kedalam Produk Domestik Regional Bruto Di Tulungagung}

Tulungagung merupakan suatu daerah yang berpotensi karena kaya akan

\footnotetext{
32 Primus Supriono. The Heritage of Batik - Identitas Pemersatu Kebanggaan Bangsa, (Yogyakarta: Andi Offset, 2016).

${ }^{33}$ Yasniasari, A., I. Noor., dan W. Y. Prasetyo. Strategi Dinas Perindustrian Dan Perdagangan Dalam Mengembangkan Industri Kreatif Sektor Kerajinan Batu Marmer Untuk Meningkatkan Daya Saing Daerah (Studi Di Dinas Perindustrian Dan Perdagangan Kabupaten Tulungagung). Jurnal Administrasi Publik (JAP), Vol. 3, No. 5, Hal. 775-781. 2015.
} 
sumber daya alam dan merupakan kabupaten terbesar dari Jawa Timur. Berikut adalah perbandingan pertumbuhan ekonomi antara Kabupaten Tulungagung dan provinsi Jawa Timur pada periode 2013-2017.

Tabel 2. Perbandingan Pertumbuhan Ekonomi Kabupaten Tulungagung dengan Pertumbungan Provinsi Jawa Timur Tahun 2013-2017

\begin{tabular}{ccc}
\hline Tahun & $\begin{array}{c}\text { Pertumbuhan } \\
\text { Ekonomi Tulungagung } \\
(\%)\end{array}$ & $\begin{array}{c}\text { Pertumbuhan } \\
\text { Ekonomi Provinsi Jawa } \\
\text { Timur (\%) }\end{array}$ \\
\hline 2013 & 6.13 & 5.56 \\
2014 & 5.46 & 5.02 \\
2015 & 4.99 & 4.79 \\
2016 & 5.02 & 5.02 \\
2017 & 5.08 & 5.45 \\
\hline
\end{tabular}

Sumber: Data diolah peneliti, 2021

Tabel di atas menunjukkan bahwa pertumbuhan ekonomi di Kabupaten Tulungagung lebih unggul di atas rata-rata pertumbuhan ekonomi provinsi jawa timur. Namun pada tahun 2016-2017 mengalami penurunan. Pada tahun 2015, pertumbuhan ekonomi mengalami penurunan hingga $4.99 \%$ dibandingkan dengan pertumbuhan pada tahun 2016 meningkat kembali sebesar 5,02\%. Peningkatan presentasi pertumbuhan ekonomi tersebut diiringi oleh pertumbuhan sektor industri yang baik. ${ }^{34}$

Kabupaten Tulungagung memiliki sektor andalan dalam bidang industri kreatif yaitu perdagangan, hotel dan restoran mencapai $26,34 \%$, pada sektor pengangkutan dan komunikasi $12,42 \%$, pada sektor pertanian sebesar $24,05 \%$, dan sektor industri pengolahan 10,26\%. Pada tahun 2013, Kabupaten Tulungagung mencapai pertumbuhan ekonomi yaitu $7,14 \%$. Kabupaten Tulungagung memiliki sumber daya alam yang sangat potensial yang mendukung perkembangan industri kreatif bagi masyarakat setempat. Kontribusi sumber daya alam tersebut antara lain pertanian berupa kelapa dan sagu, perikanan berupa ikan dan udang, tempat wisata berupa pantai, gunung, dan tempat sejarah, transportasi berupa penyeberangan dan sampan-sampan, adat istiadat, serta sumerdaya wisata bahari. Kabupaten Tulungagung memiliki pesona lokasi yang menarik untuk meningkatkan kesejahteraan masyarakat. Pedesaan di Kabupaten Tulungagung juga memiliki sumber daya alam yang berpotensi untuk mendukung terciptanya ekonomi kreatif. Data masing-masing subsektor ekonomi kreatif Kabupaten Tulungagung dapat dilihat pada tabel berikut:

\footnotetext{
${ }^{34}$ Triwidyati, E., Nining P. 2019. Pengaruh Ekspor, Pengeluaran Pemerintah, dan Angkatan Kerja yang

Bekerja Terhadap Pertumbuhan Ekonomi di Kabupaten Tulungagung. Jurnal Ekonomi Universitas Kadiri. Vol. 4, No. 2,
} 
Tabel 3. Kontribusi PDB Ekonomi Kreatif pada Masing-Masing Subsektor Kabupaten Tulungagung Tahun 2020

\begin{tabular}{llll}
\hline No & Subsektor & Persentase (\%) & Kategori \\
\hline 1 & Kuliner & 51,69 & Sedang \\
\hline 2 & Fashion & 41,05 & Sedang \\
\hline 3 & Kerajinan & 38,15 & Rendah \\
\hline 4 & Seni pertunjukan & 37,7 & Rendah \\
\hline 5 & Pasar barang seni & 9,22 & Rendah \\
\hline 6 & Televisi dan radio & 7,78 & Rendah \\
\hline 7 & Penerbitan & 6,29 & Rendah \\
\hline 8 & Arsitektur & 2,3 & Rendah \\
\hline 9 & Aplikasi dan Game Developer & 1,77 & Rendah \\
\hline 10 & Musik & 0,47 & Rendah \\
\hline 11 & Fotografi & 0,45 & Rendah \\
\hline 12 & Riset dan pengembangan & 0,26 & Rendah \\
\hline 13 & Desain produk & 0,24 & Rendah \\
\hline 14 & Software komputer & 0,06 & Rendah \\
\hline
\end{tabular}

Sumber: Diolah peneliti, 2021.

Berdasarkan tabel di atas, dapat diketahui subsektor yang berkontribusi paling besar terhadap PDB Kabupaten Tulungagung adalah kuliner sebesar 51,69\%, fashion sebesar $41,05 \%$, kerajinan sebesar $38,15 \%$, dan seni pertunjukan sebesar $37,70 \%$ dimana keempat subsektor termasuk mendominasi $>30 \%$ keatas. Subsektor kuliner dan fashion termasuk kategori sedang, artinya sudah termasuk kategori baik terhadap kontribusi pertumbuhan ekonomi Kabupaten Tulungagung. Selain kedua subsektor kuliner dan fashion, 12 lainnya termasuk kategori rendah yaitu memberikan kontribusi terhadap PDB Tulungagung antara 0,06-38,15\%.

Ekonomi kreatif berperan penting pada peningkatan PDB Kabupaten Tulungagung, dibuktikan pada tahun 2019 telah mencapai angka 39,22 triliun rupiah. Nilai tersebut telah mengalami kenaikan 2,72 triliun jika dibandingkan dengan tahun 2018 yang mencapai 36,50 triliun rupiah. Sesuai dengan harga konstan 2010, angka PDRB juga terjadi kenaikan yaitu 25,92 triliun rupiah pada tahun 2018 naik 27,30 triliun rupiah pada tahun 2019. Berdasarkan hal tersebut, Kabupaten Tulungagung mengalami pertumbuhan ekonomi sebesar 5,32\% pada tahun 2019 yang lebih pesat dibandingkan tahun sebelumnya. Perkembangan PDRB Kabupaten Tulungagung lebih jelasnya dapat dilihat pada gambar 2. 
Gambar 2. Perkembangan PDRB Tulungagung Tahun 2015-2019

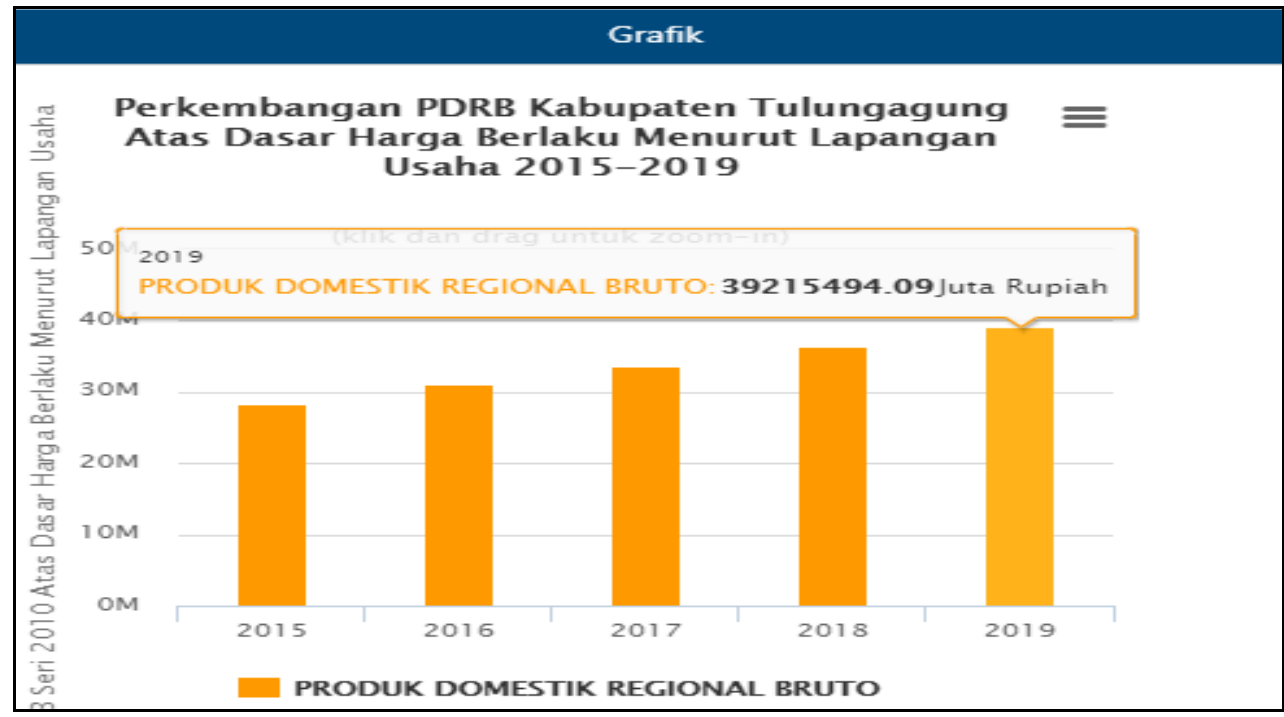

Sumber : Badan Pusat Statistik Kabupaten Tulungagung

Pada grafik 2. diketahui bahwa perkembangan PDRB Kabupaten Tulungagung tertinggi pada tahun 2019 sebesar 22,10\%, dimana angka tersebut mengalami kenaikan setelah tahun 2018 yang menyumbang 21,71\%. Kemudian lapangan usaha perdagangan besar dan kecil, reparasi mobil dan motor meningkat menjadi 20,82\% dimana pada tahun 2018 adalah 20,62\%. Sedangkan lapangan usaha dalam bidang pertanian, Kehutanan, dan Perikanan mengalami penurunan menjadi 19,04\%, dimana pada tahun 2018 mencapai 19\%. ${ }^{35}$ Berdasarkan data-data di atas, kontribusi ekonomi kreatif terhadap Produk Domestik Bruto di Kabupaten Tulungagung sudah masuk ke dalam kategori baik.

\section{Upaya Pengembangan dan Upaya Tindaklanjut Dalam Mempertahankan} Ekonomi Kreatif

Ekonomi kreatif bertugas membantu para pemilik usaha di Kabupaten Tulungagung untuk mengembangkan usahanya, dengan cara mensosialisasikan dan juga memasarkan produk-produk yang diciptakan oleh pelaku usaha ekonomi kreatif itu sendiri. Sehingga perlu bagi pelaku usaha ekonomi kreatif di kota Tulungagung untuk mengembangkan produknya karena diharapkan ekonomi kreatif ini dapat meningkatkan kesejahteraan. ${ }^{36}$ Menurut Dinas Kebudayaan dan Pariwisata ada beberapa kendala terkait dengan adanya pengembangan pada Ekonomi Kreatif. Kendala tersebut tidak hanya pada industrinya saja akan tetapi juga pada Sumber Daya Manusia (SDM) kendala yang dihadapi yaitu mulai dari kurangnya daya tarik industri dimasyarakat, rencana bisnis yang masih belum matang serta resiko dari industri kreatif yang

\footnotetext{
${ }^{35}$ https://tulungagungkab.bps.go.id

${ }^{36}$ Khusna, M. K. Peran Pemerintah Daerah Untuk Meningkatkan Ekonomi Kreatif Di Kabupaten Tulungagung. Skripsi. Jurusan Ekonomi Syariah. Fakultas Ekonomi dan Bisnis Islam IAIN Tulungagung. 2020.
} 
harus dihadapi. Bahkan teknologi juga masih menjadi kendala, hal ini dikarenakan infrastsruktur pada internet yang masih belum memadai dan dijangkau di seluruh Indonesia. Selain itu kendala yang dihadapi yaitu pelaku usaha disektor ekonomi kreatif masih minim dalam hal mengakses pembiayaan sehingga pelaku usaha sulit dalam modal yang akan digunakannya. Permasalahan yang terjadi dikalangan pelaku usaha di Tulungagung yaitu masih banyaknya pelaku usaha yang kurang akan pengetahuan dan ketrampilan dalam mengelola usahanya seperti kurangnya ketrampilan untuk mendesain produk, dan IPTEK. Selain itu kurangnya modal untuk mengembangkan usahanya juga menjadi faktor yang paling utama. Kebanyakan para pelaku usaha hanya mengandalkan kemampuan ala kadarnya dan untuk memasarkan produk mereka juga masih minim sehingga hal ini menjadi tugas bagi pemerintah daerah Tulungagung (DKP Tululngagung, 2020).

Harapan Pemerintah Daerah dengan mengusung ekonomi kreatif ini maka pelaku dari ekonomi kreatif ini diharapkan mampu atau bisa bersaing dengan pelaku daerah lain dengan menggunakan ide, keterampilan dan kreativitas yang ada. Program yang diberikan yaitu pelatihan dan pembinaan guna meningkatkan keterampilan serta pengetahuan. Selain itu pemerintah juga membantu akses permodalan, mensosialisasikan dan memberikan perizinan yang resmi. Sehingga produk mereka itu memiliki legalitas hukum resmi. Program-program yang dicanangkan untuk meningkatkan ekonomi kreatif yang dilakukan pemerintah daerah Tulungagung yaitu: melakukan pengembangan ekonomi kreatif dengan IPTEK, media, desain, seni budaya dan memberikan fasilitas bagi para pelaku ekonomi kreatif. ${ }^{37}$ Upaya yang dilakukan oleh pelaku usaha industri kreatif untuk mempertahankan produk mereka yaitu selalu berinovasi, menjaga kualitas produk, selalu mengikuti perkembangan pasar.

\section{Penutup}

Berdasarkan kajian yang telah dipaparkan dapat disimpulkan bahwa subsektor yang berkontribusi paling besar terhadap PDB Kabupaten Tulungagung adalah kuliner sebesar 51,69\%, fashion sebesar 41,05\%, kerajinan sebesar 38,15\%, dan seni pertunjukan sebesar $37,70 \%$. Kontribusi ekonomi kreatif terhadap PDB kabupaten Tulungagung pada tahun 2019 sebanyak 39,22 triliun rupiah. Perkembangan ekonomi kreatif di Tulungagung mengalami peningkatan dilihat dari pemasukan PDB dan jumlah pelaku usaha. Kontribusi ekonomi kreatif terhadap PDB di Kabupaten Tulungagung sudah masuk ke dalam kategori sedang. Usaha ekonomi kreatif diharapkan dapat mengatasi masalah pengangguran dan kemiskinan. Pemerintah daerah melakukan berbagai stategi untuk mengembangkan perekonomian rakyat yaitu dengan memberikan pelatihan, akses permodalan, pemberian izin resmi,

\footnotetext{
37 Khusna, M. K. Peran Pemerintah Daerah Untuk Meningkatkan Ekonomi Kreatif Di Kabupaten Tulungagung. Skripsi. Jurusan Ekonomi Syariah. Fakultas Ekonomi dan Bisnis Islam IAIN Tulungagung. 2020.
} 
pendampingan pemasaran dan berbagai sosialisasi. Sedangkan upaya yang dilakukan pelaku usaha adalah menjaga kualitas produk, melakukan inovasi dan mengikuti perkembangan pasar. Harapan kedepan agar semakin berkembangnya ekonomi kreatif yang maju.

Bagi peneliti selanjutnya, diharapkan lebih banyak data untuk mendukung variabel yang diteliti. Pada penelitian ini, variabel yang dibahas masih terbatas yang disebabkan karena terbatasnya ketersediaan data secara menyeluruh. Oleh karena itu penelitian ini masih perlu dikembangkan kembali, karena masih banyak aspekaspek yang bisa dikaji lebih lanjut untuk perkembangan perekonomian di Kabupaten Tulungagung.

\section{Daftar Pustaka}

Adi Fahrudin, 2012. Pemberdayaan, Partisipasi dan Penguatan Kapasitas Masyarakat, (Bandung: Humaniora)

Amir, M. Kebijakan Ekonomi Kreatif Berbasis Industri Kerajinan Unggulan dalam Upaya Mengangkat Kearifan Lokal Kabupaten Tuban, Jurnal Cakrawala, Vol.11 No.2 Desember 2017. hal.158.

Andry, M. S. N. (2010) Pendekatan Desain bagi Industri Kerajinan Kreatif: Sebuah Usulan bagi Program Implementasi Ekonomi Kreatif di Sektor Industri Kerajinan Indonesia. Disampaikan pada Seminar Nasional "Strategi UMKM dan IKM Menghadapi Asean China Free Trade Area (ACFTA) dan Implementasinya dalam Upaya Memperkuat dan Mengembangkan Kemampuan Diri".

Arif, D. (2014). Pengaruh produk domestik bruto, jumlah uang beredar, inflasi dan BI rate terhadap indeks harga saham gabungan di Indonesia periode 2007-2013. Jurnal Ilmiah Ekonomi Bisnis, 19(3).

Aristianto, A. (2018). Pemberdayaan Keluarga Lansia Melalui Usaha Ekonomi Produktif Oleh Bina Keluarga Lansia Ayah Bunda Ceria Kelurahan Tamanan Tulungagung Perspektif Ekonomi Islam.

Arjana, I Gusti Bagus, 2016, Geografi Pariwisata dan Ekonomi Kreatif, Edisi 1, Cetakan 2, Rajawali Pers, Jakarta.

Badan Ekonomi Kreatif Indonesia 2019. BEKRAF.go.id.

Badan Pusat Statistik Kabupaten Tulungagung. https://tulungagungkab.bps.go.id. diakses pada 07 Oktober 2020. 10.45 WIB.

Bappeda Kabupaten Tulungagung. 2020. http://bappeda.tulungagung.go.id/detailpost/pengembangan- ekonomikreatif-di-kabupaten-tulungagung. Diakses pada 06 Oktober 2020.

Dinas Kebudayaan dan Pariwisata tulungagung. 2020.

Ernawati Purwaningsih. 2010. Industri Kreatif berbasis Ekonomi Kreatif, Jurnal Sejarah dan Budaya, Vol 9 No.4 Juni. 
Gunawan, A., Katili, P. B., \& Lestari, M. (2017). Pemetaan potensi industri kreatif unggulan untuk meningkatkan pertumbuhan ekonomi. Journal Industrial Servicess, 3(1b).

Hidayat, R. (2015). Pemetaan Potensi Industri Kreatif Unggulan Madura. Jurnal Sains dan Teknologi Industri, 12(2), 155-165.

Hilman, Y. A., \& Nimasari, E. P. (2018). Model Program Pemberdayaan Masyarakat Desa Berbasis Komunitas. ARISTO, 6(1), 45-67.

http://www.berkaf.go.id/berita/page/9/realisasi-program-kinerja-direktorat-risetdan-pengembangan-tahun-2016.

Isyanto, P. T. (2017). Pemberdayaan Masyarakat Melalui Pengembangan Badan Usaha Milik Desa (Bum Desa) Di Desa Gogik Kecamatan Ungaran Barat Kabupaten Semarang (Doctoral dissertation, Universitas Negeri Semarang).

Juwita, R. 2020. Analisis Peran Dinas Kebudayaan Dan Pariwisata Kabupaten Tulungagung Dalam Perkembangan Perekonomian Usaha Ekonomi Kreatif. Laporan Praktik Pengalaman Lapangan Jurusan Ekonomi Syariah. Fakultas Ekonomi dan Bisnis Islam IAIN Tulungagung.

Khusna, M. K. 2020. Peran Pemerintah Daerah Untuk Meningkatkan Ekonomi Kreatif Di Kabupaten Tulungagung. Skripsi. Jurusan Ekonomi Syariah. Fakultas Ekonomi dan Bisnis Islam IAIN Tulungagung.

Malihah, N., dan S. Achiria. 2019. Peran Ekonomi Kreatif Dalam Pemberdayaan Industry Kerajinan Bambu. Jurnal Kajian Ekonomi Islam Volume 4 Nomor 1.

Noor, M. (2011). Pemberdayaan masyarakat. CIVIS, 1(2/Juli).

Polnaya, G. A, dan Darwanto. 2015. Pengembangan Ekonomi Lokal Untuk Meningkatkan Daya Saing Pada UKM Ekonomi Kreatif Batik Bakaran di Pati, Jawa Tengah. Jurnal Bisnis dan Ekonomi (JBE),Vol. 22 No.1.hal.4.

Primus Supriono. 2016. The Heritage of Batik - Identitas Pemersatu Kebanggaan Bangsa, (Yogyakarta: Andi Offset).

Puspa, D., dan Czafrani, S. (2010). Pengembangan Ekonomi Kreatif Berbasis Kearifan Lokal Oleh Pemuda Dalam Rangka Menjawab Tantangan Ekonomi Global. Jurnal UI Untuk Bangsa Seri Sosial Humaniora, 1.

Sidiq, U., Choiri, M. M., \& Mujahidin, A. (2019). Metode Penelitian Kualitatif di Bidang Pendidikan. Ponorogo, Jawa Timur, Indonesia: Penerbit CV Nata Karya. Wujud secara online pula di: http://repository. iainponorogo. ac. id/484/1/METODE [dilayari di Kuala Lumpur, Malaysia: 10hb Februari 2020].

Sunanik. 2013. Penguatan Ekonomi Kreatif dan Inovatif Berbasis Sumberdaya Desa Besuki Di Kecamatan Besuki Tulungagung. J-Adimas (Jurnal Pengabdian Kepada Masyarakat) Volume 1, Nomor 1, Juli :20-27.

Surur, Fadhil. 2017. "Pengembangan Jalur Ekonomi Kreatif di Koridor Jalan Trans Sulawesi Berbasis Sistem Informasi Geografis." 1-17. 
Suryana. (2013) Ekonomi Kreatif, Ekonomi Baru: Mengubah Ide dan Menciptakan Peluang. Jakarta Selatan.

Yasniasari, A., I. Noor., dan W. Y. Prasetyo. 2015. Strategi Dinas Perindustrian Dan Perdagangan Dalam Mengembangkan Industri Kreatif Sektor Kerajinan Batu Marmer Untuk Meningkatkan Daya Saing Daerah (Studi Di Dinas Perindustrian Dan Perdagangan Kabupaten Tulungagung). Jurnal Administrasi Publik (JAP), Vol. 3, No. 5, Hal. 775-781. 